\title{
DETEKSI FINANCIAL STATEMENT FRAUD DENGAN ANALISIS FRAUD TRIANGLE PADA PERUSAHAAN MANUFAKTUR YANG TERDAFTAR DI BURSA EFEK INDONESIA
}

\author{
Laila Tiffani \\ Universitas Islam Indonesia Yogyakarta \\ e-mail: lailatiffani93@gmail.com \\ Marfuah \\ e-mail:marfuah@uii.ac.id \\ Universitas Islam Indonesia Yogyakarta
}

\begin{abstract}
The purpose of this study is to test the effect of fraud triangle in explaining the phenomenon of financial statement frauds. To achieve these objectives, this research examines the factors that influence financial statement frauds consists of 7 (seven) independent variables are adopted from research (Skousen, Smith, and Wright 2009). Four variables of pressure elements (financial stability, personal financial need, external pressure and financial targets), the two variables of opportunity elements (nature of the industry and effective monitoring) and one variable of the elements of rationalization. Based on logistic regression analysis of the 36 companies that commit fraud and 54 companies that did not commit fraud during 2011 to 2013 concluded that there is a positive influence between financial stability (ACHANGE) and external pressure (LEV) against financial statement frauds, while the effective monitoring (IND) has negative effect on the financial statement frauds. These results give support to the fraud triangle theory in explaining the phenomenon of financial statement frauds.
\end{abstract}

Keywords: fraud, opportunity, pressure, rationalization http://dx.doi.org/10.20885/jaai.vol19.iss2.art3

\begin{abstract}
Abstrak
Tujuan penelitian ini adalah untuk menguji pengaruh fraud triangle dalam menjelaskan fenomena kecurangan laporan keuangan. Penelitian ini terdiri dari tujuh variabel independen yang diadopsi dari penelitian (Skousen, Smith, dan Wright 2009). Empat variabel dari elemen pressure (financial stability, personal financial need, external pressure,dan financial target). Dua variabel dari elemen opportunity (nature of the industry dan effective monitoring) dan satu variabel dari elemen rationalization. Berdasarkan analisis regresi logistic dari 36 perusahaan yang melakukan fraud dan 54 perusahaan yang tidak melakukan fraud selama 2011 sampai 2013 menyimpulkan bahwa ada pengaruh positif antara financial stability (ACHANGE) anad external pressure (LEV) terhadap financial statement fraud, sementara effective monitoring (IND) memiliki pengaruh negatif terhadap financial statement fraud. Hasil ini memberikan dukungan kepada fraud triangle theory dalam menjelaskan fenomena financial statement fraud.
\end{abstract}

Kata kunci: fraud, opportunity, pressure, rationalization

\section{PENDAHULUAN}

Menurut Association of Certified Fraud Examiners (ACFE), fraud adalah tindakan penipuan atau kekeliruan yang dibuat oleh seseorang atau badan yang mengetahui bahwa kekeliruan tersebut dapat mengakibatkan beberapa manfaat yang tidak baik kepada individu atau entitas. Ernst \& Young (2009) menemukan bahwa kasus fraud yang terjadi dilakukan oleh pemilik perusahaan atau dewan direksi. Selain itu, ACFE juga menemukan bahwa lebih dari setengah pelaku fraud adalah manajemen. Jika financial statement fraud 
memang sebuah masalah yang signifikan, auditor sebagai pihak yang bertanggungjawab harus dapat mendeteksi aktivitas kecurangan sebelum akhirnya berkembang menjadi skandal akuntansi yang sangat merugikan.

Skandal akuntansi telah berkembang secara luas, seperti halnya di Amerika Serikat. Spathis (2002) menjelaskan bahwa di USA, kecurangan akuntansi yang menimpa Enron menimbulkan kerugian yang sangat besar di hampir seluruh industri. Skandal akuntansi tersebut diperkirakan menimbulkan kerugian bagi Enron sebesar US\$50 miliar, ditambah lagi kerugian investor sebesar US\$32 miliar dan ribuan pegawai Enron harus kehilangan dana pensiun mereka sekitar US\$1 miliar.

Indonesia sebagai negara dengan kondisi ekonomi yang belum stabil juga terkena wabah meluasnya kasus skandal akuntansi. Berdasarkan indikasi oleh Kementerian BUMN dan pemeriksaan Bapepam (BAPEPAM 2002) ditemukan adanya salah saji dalam laporan keuangan yang mengakibatkan lebih saji (overstatement) laba bersih untuk tahun yang berakhir 31 Desember 2001 sebesar Rp 32,7 miliar yang merupakan $2,3 \%$ dari penjualan dan $24,7 \%$ dari laba bersih. Maraknya skandal kecurangan akuntansi di Indonesia juga diindikasikan dengan adanya likuidasi beberapa bank, diajukannya manajemen BUMN dan swasta ke pengadilan, kasus kejahatan perbankan, manipulasi pajak, korupsi di komisi penyelenggara pemilu, dan DPRD (Soselisa dan Mukhlasin 2008).

Pendeteksian terhadap financial statement fraud tidak selalu mendapatkan titik terang karena berbagai motivasi yang mendasarinya serta banyaknya metode untuk melakukan financial statement fraud (Brennan dan McGrath 2007). Corporate governance seringkali dikaitkan dengan fraudulent financial reporting. Pernyataan itu dibuktikan dengan penelitian Dechow, Sloan, dan Sweeney (1996) yang menemukan bahwa kejadian kecurangan paling tinggi terjadi pada perusahaan yang lemah corporate governancenya, seperti perusahaan yang lebih didominasi oleh orang dalam dan cenderung tidak memiliki komite audit. Temuan Dechow, Sloan, dan
Sweneey (1996) diperkuat kembali oleh Dunn (2004) yang menyimpulkan bahwa kecurangan lebih mungkin terjadi ketika ada konsentrasi kekuasaan di tangan orang dalam.

Dalam rangka memberikan solusi terhadap kelemahan dalam prosedur pendeteksian kecurangan di dunia, American Institute Certified Public Accountant (AICPA 2002) menerbitkan Statement of Auditing Standards No. 99 (SAS No. 99) mengenai Consideration of Fraud in a Financial Statement Audit pada Oktober 2002. Tujuan dikeluarkannya SAS No.99 adalah untuk meningkatkan efektivitas auditor dalam mendeteksi kecurangan dengan menilai pada faktor risiko kecurangan perusahaan. Faktor risiko kecurangan yang diadopsi dalam SAS No.99 didasarkan pada teori faktor risiko kecurangan (Cressey 1953).

Menurut teori Cressey (1953), terdapat tiga kondisi yang selalu hadir dalam tindakan fraud yaitu pressure, opportunity dan rationalization yang disebut sebagai fraud triangle. Ketiga kondisi tersebut merupakan faktor risiko munculnya kecurangan dalam berbagai situasi.

Penelitian di Indonesia tentang deteksi kecurangan telah dilakukan sebelumnya oleh Sukirman dan Maylia (2013) yang menunjukkan bahwa financial stability (ACHANGE), external pressure (LEV) dan financial target (ROA) dan nature of industry (RECEIVABLE) tidak berpengaruh terhadap fraud. Hanya satu variabel yang berpengaruh terhadap fraud yaitu audit report yang merupakan proksi dari rasionalisasi.

Penelitian ini berbeda dengan yang dilakukan Sukirman dan Maylia (2013) dalam beberapa hal. Pertama, Sukirman dan Maylia (2013) mengidentifikasi perusahaan melakukan fraud berdasarkan daftar resmi perusahaan yang melakukan pelanggaran sesuai dengan laporan Bapepam, sedangkan penelitian ini membedakan perusahaan dalam kelompok sampel fraud dan non fraud berdasarkan perhitungan Model Beneis-M Score (Beneish 1997). Kedua, variabel independen yang digunakan untuk mendeteksi kecurangan dalam penelitian Sukirman dan Maylia (2013) terdiri dari 5 (lima) variabel, sedangkan penelitian ini 
menggunakan 7 (tujuh) variabel. Ketiga, variabel pengukur rasionalisasi dalam penelitian Sukirman dan Maylia (2013) menggunakan audit report, sedangkan dalam penelitian ini menggunakan pergantian auditor.

Mengacu pada SAS No. 99 (AICPA 2002), faktor tekanan yang digunakan dalam penelitian ini terdiri dari financial stability, external pressure, personal financial need dan financial targets. Faktor peluang terdiri dari nature of industry dan effective monitoring, sedangkan organizational structure tidak digunakan sebagai variabel pengukur peluang, karena alasan kesulitan data. Faktor yang ketiga adalah rasionalisasi. Oleh karena itu tujuan penelitian ini adalah untuk mendeteksi financial statement fraud dengan analisis fraud triangle. Untuk mencapai tujuan tersebut, penelitian ini menguji apakah faktor tekanan yang terdiri dari financial stability, personal financial need, external pressure dan financial target dan faktor peluang yang terdiri dari nature of industry dan effective monitoring serta variabel rasionalisasi mempengaruhi financial statement fraud.

\section{TINJAUAN PUSTAKA DAN PERUMUSAN HIPOTESIS}

\section{Fraud Triangle Theory}

Fraud triangle theory merupakan suatu gagasan tentang penyebab terjadinya kecurangan yang dikemukakan oleh Cressey (1953) yang dinamakan fraud triangle. Fraud triangle menjelaskan tiga faktor yang hadir dalam setiap situasi fraud, yaitu pressure, opportunity dan rationalization seperti disajikan pada gambar 1 .

Menurut SAS No.99 (AICPA, 2002) terdapat 4 (empat) jenis kondisi yang umum terjadi pada pressure yang dapat mengakibatkan kecurangan, yaitu financial stability, external pressure, personal financial need, dan financial targets. Sedangkan opportunity terdiri dari 3 (tiga) kategori kondisi, yaitu nature of industry, ineffective monitoring, dan organizational structure. Komponen terakhir yang menyebabkan terjadinya kecurangan (fraud) adalah rasionalisasi. Rasionalisasi menyebabkan pelaku kecurangan mencari pembenaran atas perbuatannya.

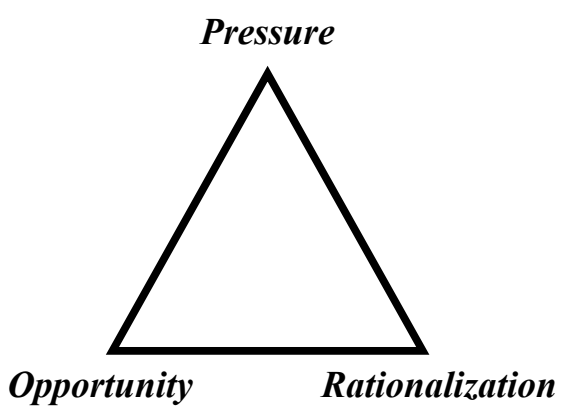

Gambar 1: Fraud Triangle (Cressey 1953)

\section{Financial Stability dan Financial Statement Fraud}

Menurut SAS No. 99 (AICPA 2002), manajer menghadapi tekanan untuk melakukan financial statement fraud ketika stabilitas keuangan (financial stability) terancam oleh keadaan ekonomi, industri, dan situasi entitas yang beroperasi. Financial stability merupakan keadaan yang menggambarkan kondisi ketidakstabilan keuangan perusahaan (Skousen et al. 2009).

Manajemen seringkali mendapatkan tekanan untuk menunjukkan bahwa perusahaan telah mampu mengelola aset dengan baik sehingga laba yang dihasilkannya juga banyak dan nantinya akan menghasilkan return yang tinggi pula untuk investor. Dengan alasan demikian, manajemen memanfaatkan laporan keuangan sebagai alat untuk menutupi kondisi stabilitas keuangan yang buruk dengan melakukan fraud.

Penelitian yang dilakukan oleh Skousen et al. (2009) menunjukkan bahwa persentase perubahan total aset (ACHANGE) berpengaruh positip terhadap financial statement fraud. Berdasarkan uraian tersebut, diajukan hipotesis sebagai berikut:

H1: Financial Stability berpengaruh positif terhadap Financial Statement Fraud.

\section{Personal Financial Need dan Financial Statement Fraud}

Personal financial need merupakan suatu kondisi ketika keuangan perusahaan turut dipengaruhi oleh kondisi keuangan para eksekutif perusahaan (Skousen et al. 2009). Beasley (1996), Committee of Sponsoring Organizations of the Treadway Commission 
(COSO) (1999), dan Dunn (2004) menunjukkan bahwa ketika eksekutif perusahaan memiliki peranan keuangan yang kuat dalam perusahaan, personal financial need dari eksekutif perusahaan tersebut akan turut terpengaruh oleh kinerja keuangan perusahaan.

Adanya kepemilikan saham oleh orang dalam perusahaan menyebabkan yang bersangkutan merasa punya hak klaim atas penghasilan dan aktiva perusahaan sehingga akan mempengaruhi kondisi keuangan perusahaan. Ketidakjelasan pemisahan antara pemilik dan kontrol dari perusahaan memicu para manajer sewenang-wenang menggunakan dana perusahaan untuk kepentingan pribadi. Contoh kepentingan pribadi yang merupakan tekanan yang dialami para manajer yang akan mendorong terjadinya kecurangan laporan keuangan antara lain tekanan keuangan, tekanan kebiasaan buruk dan tekanan berkaitan dengan pekerjaan. Semakin tinggi persentase kepemilikan saham oleh orang dalam maka praktek fraud dalam memanipulasi laporan keuangan semakin bertambah.

Penelitian yang dilakukan oleh Skousen et al. (2009) menunjukkan bahwa persentase kepemilikan saham oleh orang dalam (OSHIP) berpengaruh positif terhadap financial statement fraud. Berdasarkan uraian tersebut, diajukan hipotesis berikut:

H2: Personal Financial Need berpengaruh positif terhadap Financial Statement Fraud.

\section{External Pressure dan Financial Statement Fraud}

External pressure merupakan tekanan yang berlebihan bagi manajemen untuk memenuhi persyaratan atau harapan dari pihak ketiga. Menurut SAS No. 99, saat tekanan berlebihan dari pihak eksternal terjadi, maka terdapat risiko kecurangan terhadap laporan keuangan. Hal ini didukung oleh pendapat Skousen et al. (2009) yang menyatakan bahwa salah satu tekanan yang seringkali dialami manajemen perusahaan adalah kebutuhan untuk mendapatkan tambahan utang atau sumber pembiayaan eksternal agar tetap kompetitif, termasuk pembiayaan riset dan pengeluaran pembangunan atau modal.
Person (1999) menyatakan bahwa leverage (LEV) yang lebih besar dapat dikaitkan dengan kemungkinan yang lebih besar untuk melakukan pelanggaran terhadap perjanjian kredit dan kemampuan yang lebih rendah untuk memperoleh tambahan modal melalui pinjaman. Pernyataan tersebut juga diperkuat oleh Lou dan Wang (2009) yang menyatakan bahwa ketika perusahaan mengalami tekanan eksternal perusahaan, dapat diidentifikasi risiko salah saji material yang lebih besar akibat kecurangan.

Penelitian yang dilakukan oleh Skousen et al. (2009) menunjukkan bahwa persentase total hutang terhadap total aset (LEV) berpengaruh positif terhadap financial statement fraud. Berdasarkan uraian tersebut, diajukan hipotesis sebagai berikut:

H3: External Pressure berpengaruh positif terhadap Financial Statement Fraud.

\section{Financial Target dan Financial Statement Fraud}

Menurut SAS No.99 (AICPA, 2002), financial target adalah risiko adanya tekanan berlebihan pada manajemen untuk mencapai target keuangan yang dipatok oleh direksi atau manajemen, termasuk tujuan-tujuan penerimaan insentif dari penjualan maupun keuntungan. Skousen et al. (2009) mengatakan bahwa Return on asset (ROA) sering digunakan dalam menilai kinerja manajer dan dalam menentukan bonus, kenaikan upah, dan lain-lain.

Semakin tinggi ROA yang ditargetkan perusahaan, maka semakin rentan manajemen akan melakukan manipulasi laba yang menjadi salah satu bentuk kecurangan sehingga memiliki hubungan positif dengan kecurangan laporan keuangan. Berdasarkan uraian tersebut, diajukan hipotesis sebagai berikut:

H4: Financial Targets berpengaruh positif terhadap Financial Statement Fraud.

\section{Nature of Industry dan Financial Statement Fraud}

Nature of Industry merupakan keadaan ideal suatu perusahaan dalam industri. Pada laporan keuangan terdapat akun-akun tertentu yang besarnya saldo ditentukan oleh perusahaan 
berdasarkan suatu estimasi, misalnya akun piutang tak tertagih dan akun persediaan usang. Summers dan Sweeney (1998) mencatat bahwa akun piutang dan persediaan memerlukan penilaian subjektif dalam memperkirakan tidak tertagihnya piutang. Summers dan Sweeney, (1998) juga menyatakan bahwa manajer akan fokus terhadap kedua akun tersebut jika berniat melakukan manipulasi pada laporan keuangan.

Penelitian yang dilakukan oleh Summers dan Sweeney (1998) menunjukkan bahwa rasio perubahan dalam piutang usaha (RECEIVABLE) berpengaruh positif terhadap financial statement fraud. Berdasarkan uraian tersebut, diajukan hipotesis sebagai berikut:

H5: Nature of Industry berpengaruh positif terhadap Financial Statement Fraud.

\section{Effective Monitoring dan Financial Statement Fraud}

Fraud dapat diminimalkan salah satunya dengan mekanisme pengawasan yang baik. Komite audit dipercaya dapat meningkatkan efektifitas pengawasan perusahaan. Beasly, Dana dan Terry (2010) menyatakan bahwa anggota komite audit yang lebih besar dapat mengurangi insiden fraud.

Penelitian yang dilakukan oleh Skousen et al. (2009) menunjukkan bahwa proporsi anggota komite audit independen (IND) berpengaruh negatif terhadap kecurangan laporan keuangan. Berdasarkan uraian tersebut, diajukan hipotesis sebagai berikut:

H6: Effective monitoring berpengaruh negatif terhadap Financial Statement Fraud.

\section{Rationalization dan Financial Statement Fraud}

Auditor adalah pengawas penting dalam laporan keuangan. Informasi tentang perusahaan yang terindikasi terjadi kecurangan, biasanya juga diketahui dari auditor. Perusahaan yang melakukan fraud lebih sering melakukan pergantian auditor, karena manajemen perusahaan cenderung berusaha mengurangi kemungkinan pendeteksian oleh auditor lama terkait tindak kecurangan laporan keuangan.
Lou dan Wang (2009) menyatakan bahwa sebuah perusahaan bisa mengganti auditor untuk mengurangi kemungkinan pendeteksian kecurangan laporan keuangan oleh pihak auditor. Loebbecke, Eining, dan Willingham (1989) menunjukkan bahwa 36 persen dari kecurangan dalam sampel mereka dituduhkan dalam dua tahun awal masa jabatan auditor. Berdasarkan uraian tersebut, diajukan hipotesis sebagai berikut:

H7: Rationalization berpengaruh positif terhadap Financial Statement Fraud.

\section{Kerangka Pemikiran Teoritis}

Dari uraian di atas dapat digambarkan dalam kerangka pemikiran teoritis seperti pada Gambar 2 di bawah.

\section{METODA PENELITIAN}

\section{Populasi dan Sampel Penelitian}

Populasi dalam penelitian ini adalah perusahaan yang terdaftar (listed) di Bursa Efek Indonesia (BEI) tahun 2011-2013. Metode pengambilan sampel menggunakan metode purposive sampling dengan kriteria berikut:

1. Perusahaan manufaktur yang terdaftar di Busa Efek Indonesia berturut-turut selama periode tahun 2011 - 2013.

2. Perusahaan yang menyajikan annual report lengkap dalam website perusahaan atau website BEI secara berturut-turut selama periode pengamatan.

3. Perusahaan terindikasi melakukan manipulasi (fraud) minimal 1 kali dalam 3 tahun pengamatan.

Untuk menentukan apakah perusahaan terindikasi melakukan manipulasi (fraud) atau tidak, peneliti menggunakan model perhitungan Beneish M-Score. Jika Benesih M-Score lebih besar dari -2.22 mengindikasikan bahwa laporan keuangan telah dimanipulasi dan jika skor lebih kecil dari -2.22 maka perusahaan dikategorikan sebagai perusahaan yang tidak melakukan manipulasi (non fraud). 


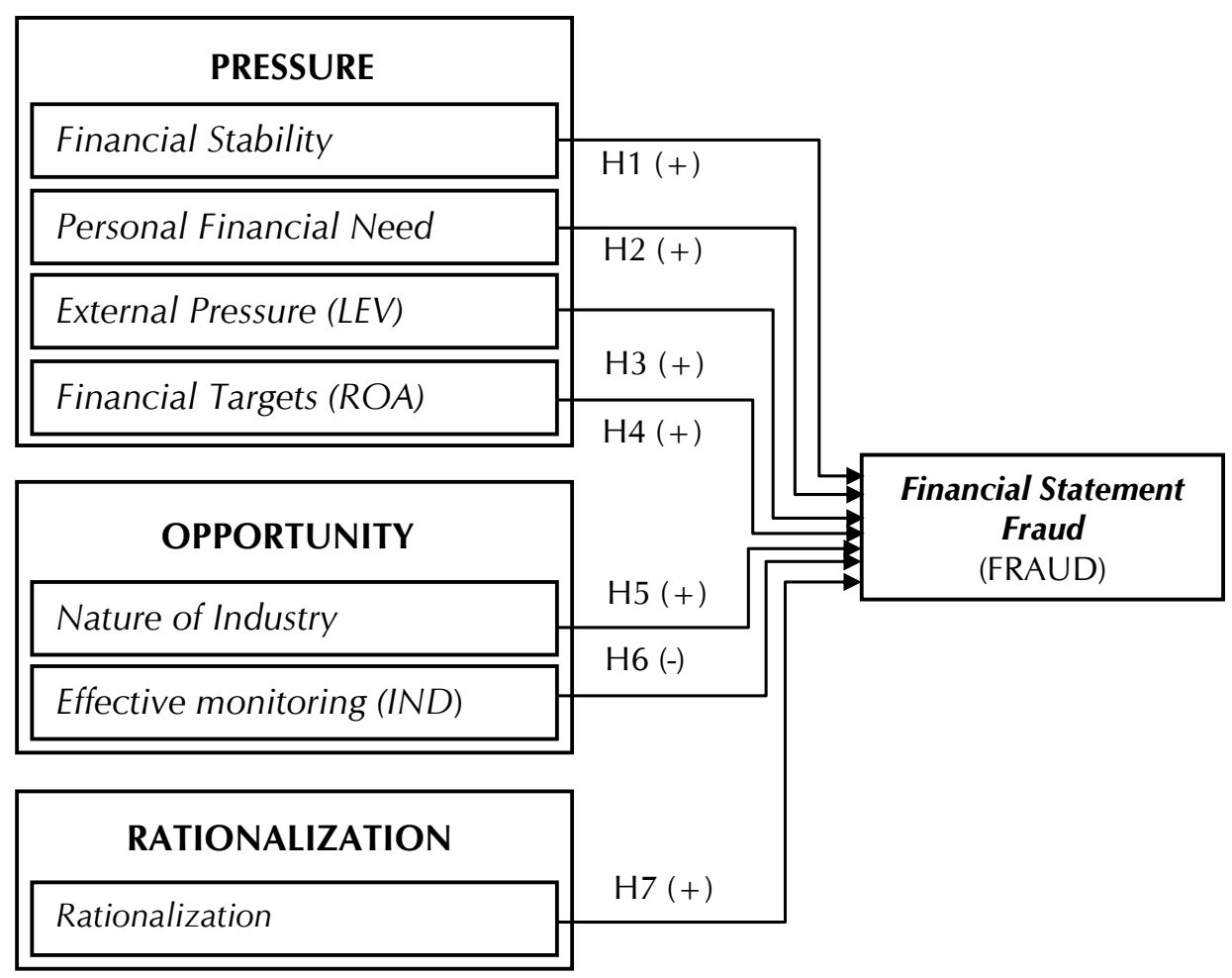

Gambar 2: Kerangka Pemikiran Teoritis

Tabel 1: Proses Pemilihan Sampel

\begin{tabular}{clc}
\hline No & \multicolumn{1}{c}{ Keterangan } & Total \\
\hline 1. & Perusahaan manufaktur yang terdaftar di BEI berturut-turut selama tahun 2011 -2013 & 136 \\
2. & $\begin{array}{l}\text { Perusahaan tidak mengeluarkan annual report secara berturut-turut selama tahun } \\
\text { pengamatan }\end{array}$ & $(36)$ \\
3. & $\begin{array}{l}\text { Perusahaan tidak terindikasi melakukan manipulasi (fraud) minimal 1 kali dalam 3 } \\
\text { tahun pengamatan }\end{array}$ & $(70)$ \\
& Perusahaan terindikasi melakukan fraud minimal 1 kali dalam 3 tahun pengamatan & 30 \\
\hline
\end{tabular}

Sumber : Data Diolah, 2015

Berdasarkan kriteria tersebut, jumlah perusahaan manufaktur yang terindikasi melakukan fraud minimal 1 kali dalam 3 tahun pengamatan adalah sebanyak 30 perusahaan, sehingga sampel keseluruhan selama 3 tahun sebanyak 90 sampel. Dari 90 sampel terpilih, kemudian diklasifikasikan menjadi 2 kelompok sampel, yaitu kelompok perusahaan yang terindikasi melakukan fraud sebanyak 36 dan yang tidak melakukan fraud 54. Adapun proses pemilihan sampel disajikan pada tabel 1 .

\section{Definisi dan Pengukuran Variabel Penelitian Variabel dependen}

Variabel dependen dalam penelitian ini adalah financial statement fraud (FRAUD) yang diukur dengan menggunakan model Beneish M-Score. Beneish M-Score diukur dengan menggunakan 8 (delapan) rasio keuangan untuk mengidentifikasikan apakah perusahaan memiliki indikasi untuk memanipulasi pendapatan dalam laporan keuangan (Beneish 1997). Delapan rasio keuangan dan pengukurannya disajikan pada tabel 2 .

Setelah dilakukan perhitungan kedelapan rasio tersebut, kemudian diformulasikan kedalam rumus Beneish M Score Model:

$$
\begin{aligned}
\text { M-Score }= & -4.84+0.920 \text { DSRI }+0.528 \text { GMI }+ \\
& 0.404 \text { AQI }+0.892 \text { SGI }+0.115 \\
& \text { DEPI - 0.172 SGAI }-0.327 \text { LVGI } \\
& +4.697 \text { TATA }
\end{aligned}
$$


Tabel 2: Rasio Keuangan Untuk Mengukur Beneish- M Score

\begin{tabular}{|c|c|c|}
\hline No & Rasio Keuangan & Rumus \\
\hline \multirow{2}{*}{1} & \multirow{2}{*}{$\begin{array}{l}\text { Days Sales in Receivable } \\
\text { Index (DSRI) }\end{array}$} & \multirow{2}{*}{$D S R I=\frac{(\text { Net Receivables } t / \text { Salest })}{(\text { Net Receivables } t-1 / \text { Salest }-1)}$} \\
\hline & & \\
\hline \multirow[b]{2}{*}{2} & \multirow{2}{*}{$\begin{array}{l}\text { Gross Margin Index } \\
(\mathrm{GMI})\end{array}$} & \multirow{2}{*}{ GMI $=\frac{[(\text { Salest }-1-\text { CoGS } t-1) / \text { Sales } t-1]}{[(\text { Sales } t-\text { CoGS } t) / \text { Salest } t]}$} \\
\hline & & \\
\hline \multirow{2}{*}{3} & \multirow{2}{*}{ Asset Quality Index (AQI) } & \multirow{2}{*}{$A Q I=\frac{(T A t-(C A t+P P E t) / T A t)}{(T A t-1-(C A t-1+P P E t-1) / T A t-1)}$} \\
\hline & & \\
\hline \multirow{2}{*}{4} & \multirow{2}{*}{ Sales Growth Index (SGI) } & \multirow{2}{*}{$S G I=\frac{\text { Salest }}{\text { Salest }-1}$} \\
\hline & & \\
\hline 5 & Depreciation Index (DEPI) & $D E P I=\frac{(\text { Depreciationt }-1 /(\operatorname{PPE} t-1+\text { Depreciation } t-1)]}{[(\text { Depreciation } t /(P P E t+\text { Depreciation } t)]}$ \\
\hline \multirow[b]{2}{*}{6} & \multirow{2}{*}{$\begin{array}{l}\text { Sales General and } \\
\text { Administrative Expenses } \\
\text { Index (SGAI) }\end{array}$} & \multirow{2}{*}{$S G A I=\frac{(\text { SGRA Expense } t / \text { Sales } t)}{(\text { SG\&A Expense } t-1 / \text { Salest } t-1)}$} \\
\hline & & \\
\hline \multirow[b]{2}{*}{7} & \multirow[b]{2}{*}{ Leverage Index (LVGI) } & {$[($ Current Liabilitiest + Long Term Debt $t) /$ Total Assets $t]$} \\
\hline & & LVGT $=\frac{[(\text { Current Liabilities } t-1+\text { Long Term Debtt }-1) / \text { Total Assets } t-1}{1}$ \\
\hline & & $=\frac{\text { (Net Income from Continuing Operationst }- \text { Cash Flows from Op }}{}$ \\
\hline 8 & $\begin{array}{l}\text { 1 otal Accruals to lotal } \\
\text { Assets (TATA) }\end{array}$ & TotalAssets $t$ \\
\hline
\end{tabular}

Sumber: Skousen et al. (2009)

Jika Benesih M-Score lebih besar dari -2.22, dikategorikan sebagai perusahaan yang melakukan fraud. Sedangkan jika skor lebih kecil dari -2.22 , dikategorikan sebagai perusahaan yang tidak melakukan fraud (non fraud). Selanjutnya perusahaan yang melakukan fraud diberi skor 1 dan yang tidak melakukan fraud (non fraud) diberi skor 0.

\section{Variabel independen}

Variabel independen dalam penelitian ini merupakan variabel yang dikembangkan dari ketiga komponen fraud triangle, yaitu (1) Pressure, (2) Opportunity dan (3) Rationalization. Pada penelitian ini pengukuran variabel independen mengacu pada Skousen et al. (2009), akan tetapi tidak memasukkan variabel organizational structure, karena kesulitan memperoleh data. Tabel 3 berikut menyajikan variabel independen dan pengukurannya.

Tabel 3: Variabel Independen dan Pengukurannya

\begin{tabular}{|c|c|c|}
\hline $\begin{array}{l}\text { Fraud Risk } \\
\text { Factor }\end{array}$ & Nama Variabel & Pengukuran Variabel \\
\hline \multirow{7}{*}{ Pressure } & \multirow{2}{*}{$\begin{array}{l}\text { Financial Stability } \\
\text { (ACHANGE) }\end{array}$} & Total Aset $t-$ Total Aset $t-\mathbf{1}$ \\
\hline & & $=T \frac{\text { Total Aset t }}{T}$ \\
\hline & $\begin{array}{l}\text { External Pressure } \\
(L E V)\end{array}$ & $=\frac{\text { Total Hutang }}{\text { Total Aset }}$ \\
\hline & \multirow{2}{*}{$\begin{array}{l}\text { Personal Financial } \\
\text { Need }(O S H I P)\end{array}$} & Total saham yang dimiliki orang dalam \\
\hline & & Total saham biasa yang beredar \\
\hline & \multirow{2}{*}{$\begin{array}{l}\text { Financial Targets } \\
(\text { ROA) }\end{array}$} & $=\frac{\text { Laba sotelah pajak } t-1}{1}$ \\
\hline & & Total Aset t-1 \\
\hline \multirow{4}{*}{ Opportunity } & \multirow{2}{*}{$\begin{array}{l}\text { Nature Of Industry } \\
\text { (RECEIVABLE) }\end{array}$} & $=\left(\frac{\text { Piutangt }}{-}-\right.$ \\
\hline & & $(\overline{\text { Penjualan } t} \overline{\text { Penjualan } t-1})$ \\
\hline & \multirow{2}{*}{$\begin{array}{l}\text { Ineffective } \\
\text { Monitoring }\end{array}$} & Iumlah anggota komite audit independen \\
\hline & & Jumlah total komite audit \\
\hline Rationalization & $\begin{array}{l}\text { Rationalization } \\
(A U D C H A N G E)\end{array}$ & $\begin{array}{l}1 \text { (satu) untuk perusahaan yang melakukan pergantian } \\
\text { auditor sedangkan } 0 \text { (nol) untuk sebaliknya. }\end{array}$ \\
\hline
\end{tabular}

Sumber: Skousen et al. (2009) 


\section{Metode Analisis Data}

Metode analisis data yang digunakan untuk menguji hipotesis adalah model regresi logistik dengan rumus:

FRAUD $=\alpha+\beta_{1}$. ACHANGE $+\beta_{2}$. OSHIP + $\beta_{3}$. LEV $+\beta_{4}$. ROA $+\beta_{5}$. RECEIVABLE $+\beta_{6}$. IND $+\beta_{7}$. AUDCHANGE $+€$

Keterangan :

FRAUD: variabel dummy, kode 1 (satu) untuk perusahaan yang melakukan kecurangan laporan keuangan, kode 0 (nol) untuk yang tidak

$\alpha$ : konstanta

$\beta$ : koefisien variabel

ACHANGE: rasio perubahan aset selama dua tahun

OSHIP : komposisi saham yang dimiliki manajemen

LEV : rasio leverage

ROA : rasio return on asset (ROA)
RECEIVABLE: rasio perubahan piutang usaha IND : proporsi dewan komisaris independen AUDCHANGE : pergantian auditor

$€$ : error term

Selain itu juga dilakukan pengujian tambahan yaitu dengan Independent Sample T-Test untuk menguji perbedaan karakteristik dari kedua kelompok sub sampel fraud dan non fraud berdasarkan 7 (tujuh) variabel independen.

\section{HASIL DAN PEMBAHASAN}

\section{Deskripsi Data}

Sebelum dilakukan pengujian hipotesis, terlebih dahulu disajikan deskripsi data variabel penelitian yang meliputi nilai minimum, maksimun, mean dan standar deviasi pada tabel 4. Panel A menyajikan deskripsi data untuk total sampel, Panel B untuk sub sampel fraud dan Panel C untuk sub sampel non fraud.

Tabel 4: Deskrisi Variabel Penelitian

Panel A : Total Sampel

\begin{tabular}{lcrrrr}
\hline & $\mathrm{n}$ & \multicolumn{1}{c}{ Minimum } & \multicolumn{1}{c}{ Maximum } & \multicolumn{1}{l}{ Mean } & \multicolumn{1}{c}{ Std. Deviation } \\
\hline ACHANGE & 90 &,- 3094 & 1,5881 &, 192119 &, 2101762 \\
OSHIP & 90 &, 0000 &, 2888 &, 062571 &, 0887271 \\
LEV & 90 &, 0366 & 1,0072 &, 454215 &, 2018919 \\
ROA & 90 &, 0029 &, 3211 &, 082886 &, 0660785 \\
RECEIVABLE & 90 &,- 1049 &, 0896 &, 009437 &, 0353497 \\
IND & 90 &, 2500 &, 6667 &, 364815 &, 1064242
\end{tabular}

Sumber : Hasil Olah Data, 2015

Panel B : Sub Sampel Fraud

\begin{tabular}{lcrrrr}
\hline & $\mathrm{n}$ & \multicolumn{1}{c}{ Minimum } & \multicolumn{1}{c}{ Maximum } & \multicolumn{1}{c}{ Mean } & \multicolumn{1}{c}{ Std. Deviation } \\
\hline ACHANGE & 36 &,- 3094 &, 5279 &, 224348 &, 1490865 \\
OSHIP & 36 &, 000010 &, 256100 &, 05381639 &, 086173078 \\
LEV & 36 &, 0366 & 1,0072 &, 521713 &, 2020039 \\
ROA & 36 &, 0129 &, 2806 &, 084656 &, 0593531 \\
RECEIVABLE & 36 &,- 0521 &, 0611 &, 012911 &, 0253889 \\
IND & 36 &, 2500 &, 3333 &, 324074 &, 0265606 \\
\hline
\end{tabular}

Sumber : Hasil Olah Data, 2015

PanelC : Sub Sampel Non Fraud

\begin{tabular}{lcrrrr}
\hline & $\mathrm{n}$ & \multicolumn{1}{c}{ Minimum } & \multicolumn{1}{c}{ Maximum } & \multicolumn{1}{c}{ Mean } & \multicolumn{1}{c}{ Std. Deviation } \\
\hline ACHANGE & 54 &,- 1824 & 1,5881 &, 170633 &, 2415057 \\
OSHIP & 54 &, 000010 &, 288800 &, 06840796 &, 090715204 \\
LEV & 54 &, 0372 &, 7611 &, 409217 &, 1906355 \\
ROA & 54 &, 0029 &, 3211 &, 081706 &, 0707269 \\
RECEIVABLE & 54 &,- 1049 &, 0896 &, 007122 &, 0407315 \\
IND & 54 &, 2500 &, 6667 &, 391975 &, 1291295 \\
\hline
\end{tabular}

Sumber : Hasil Olah Data, 2015 


\section{Analisis Regresi Logistik}

Tabel 5: Hasil Uji Regresi Logistik

Persamaan Regresi:

\begin{tabular}{|c|c|c|c|c|c|c|c|}
\hline Variabel & Prediksi & B & S.E. & Wald & Sig. & $\operatorname{Exp}(B)$ & Kesimpulan \\
\hline ACHANGE & + & 3,152 & 1,585 & 3,955 &, 047 & 23,394 & Hal didukung \\
\hline OSHIP & + &,- 401 & 3,047 &, 017 &, 895 &, 669 & Ha2 tidak didukung \\
\hline LEV & + & 2,994 & 1,522 & 3,872 & 049 & 19,971 & Ha3 didukung \\
\hline ROA & + & 2,608 & 4,306 & ,367 &, 545 & 13,578 & Ha4 tidak didukung \\
\hline RECEIVABLE & + &, 059 & 7,930 &, 000 & ,994 & 1,060 & Ha5 tidak didukung \\
\hline IND & & $-22,705$ & 8,684 & 6,836 & ,009 &, 000 & Ha6 didukung \\
\hline AUDCHANGE & + & ,984 &, 926 & 1,128 & ,288 & 2,675 & Ha7 tidak didukung \\
\hline Constant & & 4,973 & 2,713 & 3,361 & 067 & 144,496 & \\
\hline \multicolumn{8}{|c|}{$\begin{array}{l}\text { Hosmer and Lemeshow Test: Chi-square }=13,415 \text {, Sig. }=0,098 \\
\text { Overall Model Fit Test }:-2 \text { Log Likehood Block Number }=0 \text { adalah 121,143, } \\
-2 \text { Log Likehood Block Number }=1 \text { adalah 101,682 } \\
\text { Nagel Karke R Square }: 0,342 \\
\text { Cox \& Snell R Square } 0.253\end{array}$} \\
\hline
\end{tabular}

Sumber: Hasil Olah Data, 2015.

Hasil uji hipotesis penelitian dengan model regresi logistik disajikan pada tabel 5 . Langkah pertama yang dilakukan adalah menilai kelayakan model regresi. Berdasarkan hasil uji Hosmer and Lemeshow diperoleh nilai Chi-square sebesar 13,415 dengan sig 0,098 . Hal ini menunjukkan bahwa model mampu memprediksi nilai observasi karena cocok dengan data observasinya.

Langkah kedua adalah menilai keseluruhan model regresi dengan membandingkan nilai -2 Log Likelihood Block Number $=0$ dan -2 Log Likelihood Block Number $=1$. Adanya penurunan yang signifikan nilai -2 Log Likelihood Block Number $=0$ sebesar 121,143 menjadi 101,682 pada model -2 Log Likelihood Block Number $=1$, menunjukkan bahwa model regresi dengan memasukkan semua variabel independen lebih baik atau dengan kata lain model yang dihipotesiskan fit dengan data.
Prediksi ketepatan model juga dapat menggunakan matrik klasifikasi yang menghitung nilai estimasi yang benar dan yang salah pada variable dependen. Matrik klasifikasi menunjukkan kekuatan prediksi dari model regresi untuk memprediksi kemungkinan terjadinya kecurangan. Hasil nilai Uji klasifikasi disajikan pada tabel 6.

Berdasarkan tabel 6 di atas menunjukkan bahwa secara keseluruhan $71,1 \%$ sampel dapat diprediksikan dengan tepat oleh model regresi logistik ini. Tingginya persentase ketepatan tabel klasifikasi tersebut mendukung tidak adanya perbedaan yang signifikan terhadap data hasil prediksi dan data observasinya yang menunjukkan sebagai model regresi logistik yang baik.

Langkah selanjutnya adalah menguji pengaruh dari masing-masing variabel independen terhadap variabel dependennya.

Tabel 6: Hasil Uji Klasifikasi

\begin{tabular}{|c|c|c|c|c|c|}
\hline \multicolumn{6}{|c|}{ Classification Table $^{\mathrm{a}}$} \\
\hline & \multirow{3}{*}{ Observed } & & \multicolumn{3}{|c|}{ Predicted } \\
\hline & & & \multicolumn{2}{|c|}{ FRAUD } & \multirow{2}{*}{$\begin{array}{c}\text { Percentage } \\
\text { Correct }\end{array}$} \\
\hline & & & 0 & 1 & \\
\hline \multirow{3}{*}{ Step 1} & \multirow{2}{*}{ FRAUD } & 0 & 45 & 9 & 83,3 \\
\hline & & 1 & 17 & 19 & 52,8 \\
\hline & \multicolumn{4}{|c|}{ Overall Percentage } & 71,1 \\
\hline
\end{tabular}

Sumber : Hasil Olah Data, 2015 
Pengaruh Financial Stability Terhadap Financial Statement Fraud

Berdasarkan tabel 05, koefisien variabel ACHANGE bernilai positif 3,152 dengan nilai signifikansi 0,047 , artinya financial stability (ACHANGE) berpengaruh positif signifikan terhadap financial statement fraud. Hasil ini mengindikasikan bahwa semakin tinggi kondisi ketidakstabilan keuangan perusahaan, maka kemungkinan perusahaan melakukan financial statement fraud juga semakin tinggi.

Hasil ini sesuai dengan pernyataan Skousen et al. (2009) bahwa manajer menghadapi tekanan untuk melakukan financial statement fraud ketika stabilitas keuangan (financial stability) terancam oleh keadaan ekonomi, industri, dan situasi entitas yang beroperasi. Artinya dengan adanya ketidakstabilan keuangan, akan memicu terjadinya pelanggaranpelanggran yang dilakukan manajemen.

Loebbecke et al. (1989) menunjukkan bahwa kasus dimana perusahaan mengalami pertumbuhan industri di bawah rata-rata, manajemen mungkin melakukan manipulasi laporan keuangan untuk meningkatkan prospek perusahaan. Kondisi perusahaan yang tidak stabil akan menimbulkan tekanan bagi manajemen karena kinerja perusahaan terlihat menurun di mata publik sehingga akan menghambat aliran dana investasi di tahun mendatang.

\section{Pengaruh Personal Financial Need Terhadap Financial Statement Fraud}

Koefisien regresi personal financial need (OSHIP) adalah -0,401 dengan signifikansi sebesar 0,895, maka dapat disimpulkan bahwa personal financial need (OSHIP) tidak berpengaruh signifikan terhadap financial statement fraud. Hasil ini kemungkinan disebabkan karena masih rendahnya rata-rata kepemilikan manajerial dalam perusahaan sampel, yaitu sebesarr 0,062571 atau 6,2571\%.

Kepemilikan manajerial yang rendah mengindikasikan bahwa pada perusahaan sampel telah terjadi pemisahan yang jelas antara pemegang saham sebagai pemilik yang mengontrol jalannya perusahaan dan manajer sebagai pengelola perusahaan. Adanya pemi- sahan yang jelas menyebabkan manajer tidak mempunyai kemampuan yang cukup untuk melakukan kecurangan laporan keuangan. Hasil penelitian ini tidak sesuai dengan penelitian yang dilakukan oleh Skousen et al. (2009) yang menyimpulkan bahwa persentase kepemilikan saham oleh orang dalam (OSHIP) berpengaruh positif terhadap financial statement fraud.

\section{Pengaruh External Pressure Terhadap Personal Financial Need}

Koefisien regresi variabel LEVERAGE bernilai positif 2,994 dengan nilai signifikansi sebesar 0,049 sehingga dapat disimpulkan bahwa external pressure (LEVERAGE) berpengaruh positif signifikan terhadap financial statement fraud. Artinya semakin besar tekanan dari pihak eksternal maka akan meningkatkan potensi manajemen untuk melakukan kecurangan laporan keuangan.

Hasil penelitian ini sejalan dengan pendapat Person (1999) yang menyatakan bahwa leverage (LEV) yang lebih besar dapat dikaitkan dengan kemungkinan yang lebih besar untuk melakukan pelanggaran terhadap perjanjian kredit dan kemampuan yang lebih rendah untuk memperoleh tambahan modal melalui pinjaman. Hasil ini juga mendukung pendapat Lou dan Wang (2009) yang menyatakan bahwa ketika perusahaan mengalami tekanan eksternal perusahaan, dapat diidentifikasi risiko salah saji material yang lebih besar akibat kecurangan. Hasil penelitian ini sesuai dengan penelitian Skousen et al. (2009) yang menyimpulkan bahwa external pressure (LEVERAGE) berpengaruh positif terhadap financial statement fraud.

\section{Pengaruh Financial Target Terhadap Financial Statement Fraud}

Koefisien variabel ROA bernilai positif 2,608 dengan signifikansi sebesar 0,545 , maka dapat disimpulkan bahwa financial target (ROA) tidak berpengaruh signifikan terhadap financial statement fraud. Artinya bahwa besar kecilnya tingkat ROA yang ditargetkan perusahaan tidak mempengaruhi manajemen untuk melakukan kecurangan laporan keuangan. 
Hasil penelitian ini berbeda dengan temuan Skousen et al. (2009) yang menyimpulkan bahwa financial target (ROA) berpengaruh positif terhadap financial statement fraud. Tidak berpengaruhnya ROA terhadap financial statement fraud pada penelitian ini kemungkinan disebabkan karena manajer menganggap bahwa besarnya target ROA perusahaan masih dinilai wajar dan bisa dicapai. Manajer tidak menganggap bahwa target ROA tersebut sebagai target keuangan yang sulit untuk dicapai sehingga besarnya target ROA tidak memicu terjadinya kecurangan laporan keuangan yang dilakukan oleh manajemen.

\section{Pengaruh Nature of Industry Terhadap Financial Statement Fraud}

Koefisien variabel RECEIVABLE bernilai positif 0,059 dengan nilai signifikansi sebesar 0,994, maka dapat disimpulkan bahwa nature of industry (RECEIVABLE) tidak berpengaruh signifikan terhadap financial statement fraud, rtinya bahwa besar kecilnya rasio perubahan dalam piutang usaha tidak memicu manajemen untuk melakukan kecurangan laporan keuangan.

Hasil penelitian ini berbeda dengan penelitian yang dilakukan oleh Summers dan Sweeney (1998) yang menyimpulkan bahwa nature of industry (RECEIVABLE) berpengaruh positif terhadap financial statement fraud.

Tidak berpengaruhnya variabel nature of industry (RECEIVABLE) terhadap financial statement fraud pada penelitian ini kemungkinan disebabkan nilai rata-rata perubahan piutang usaha (RECEIVABLE) pada sub sampel fraud dan sub sampel non fraud besarnya tidak jauh berbeda, yaitu masingmasing sebesar 0,012911 pada sub sampel fraud dan 0,007122 pada sub sampel non fraud. Hal ini mengindikasikan bahwa perusahaan yang masuk dalam kelompok sub sampel fraud maupun sub sampel non fraud mempunyai sifat industri yang tidak berbeda, sehingga RECEIVABLE tidak dapat digunakan untuk mendeteksi terjadinya kecurangan laporan keuangan dalam perusahaan.
Pengaruh Effective Monitoring Terhadap Financial Statement Fraud

Koefisien variabel effective monitoring (IND) sebesar -22,705 dengan nilai signifikansi sebesar 0,009, maka disimpulkan bahwa effective monitoring (IND) berpengaruh negatiF signifikan terhadap financial statement fraud. Artinya bahwa semakin tinggi efektifitas pengawasan perusahaan akan menurunkan potensi manajemen untuk melakukan kecurangan laporan keuangan.

Hasil penelitian ini sesuai dengan Skousen et al. (2009) yang menyimpulkan bahwa effective monitoring (IND) berpengaruh negatip terhadap financial statement fraud. Fraud dapat diminimalkan salah satunya dengan mekanisme pengawasan yang baik. Komite audit dipercaya dapat meningkatkan efektifitas pengawasan perusahaan. Artinya bahwa semakin besar proporsi komite audit independen, maka proses pengawasan yang dilakukannya akan semakin efektif sehingga akan menurunkan potensi manajemen untuk melakukan kecurangan laporan keuangan.

\section{Pengaruh Rationalization Terhadap Finan- cial Statement Fraud}

Koefisien variabel AUDCHANGE bernilai positif 0,984 dengan nilai signifikansi sebesar 0,228, maka dapat disimpulkan bahwa rationalization (AUDCHANGE) tidak berpengaruh signifikan terhadap financial statement fraud. Artinya bahwa pergantian auditor yang dilakukan perusahaan tidak dapat digunakan untuk mendeteksi terjadinya kecurangan laporan keuangan dalam perusahaan.

Hasil penelitian ini berbeda dengan temuan Sorenson et al. (1983) dan Skousen et al. (2009) yang menunjukkan bahwa rationalization (AUDCHANGE) berpengaruh positif terhadap financial statement fraud. Hasil ini kemungkinan disebabkan karena perusahaan sampel yang melakukan pergantian auditor, bukan disebabkan perusahaan ingin mengurangi kemungkinan pendeteksian kecurangan laporan keuangan oleh auditor lama, tetapi lebih dikarenakan perusahaan ingin mentaati Peraturan Menteri Keuangan Republik Indonesia Nomor 17/PMK.01/2008 pasal 3 
ayat 1 yang menyatakan bahwa pemberian jasa audit umum atas laporan keuangan dari suatu entitas dapat dilakukan paling lama untuk 6 (enam) tahun buku berturut-turut oleh KAP yang sama dan 3 (tiga) tahun berturutturut oleh auditor yang sama kepada satu klien yang sama.

\section{Pengujian Tambahan}

Pengujian tambahan dilakukan dengan uji beda Independend Sample T-Test untuk menguji apakan masing-masing variabel independen dalam penelitian ini mempunyai karakteristik yang berbeda secara signifikan pada kedua kelompok sub sampel penelitian. Hasil pengujian dengan Independent Sample T-Test disajikan pada tabel 7.

Berdasarkan tabel 7 di atas, dapat disimpulkan bahwa variabel external pressure (LEV) dan effective monitoring (IND) berbeda secara signifikan pada subsampel perusahaan yang melakukan fraud dan yang tidak melakukan fraud. Artinya berdasarkan uji beda Independent sample T-Test, kedua variabel tersebut dapat digunakan untuk mendeteksi potensi kecurangan yang terjadi pada perusahaan. Semakin tinggi leverage dan semakin kecil proporsi komite audit independen, maka potensi terjadinya kecurangan laporan keuangan dalam perusahaan akan semakin tinggi. Hasil ini mendukung hasil pengujian hipotesis ketiga dan keenam dengan menggunakan analisis regresi logistik.

\section{SIMPULAN}

Berdasarkan pengujian terhadap 7 (tujuh) hipotesis yang dilakukan dengan menggunakan analisis regresi logistik, disimpulkan sebagai berikut: 1) Financial stability (ACHANGE) dan external pressure (LEVERAGE) berpengaruh positif signifikan terhadap kecurangan laporan keuangan. Hal ini mengindikasikan bahwa perusahaan yang mempunyai ketidakstabilan keuangan dan tekanan eksternal yang tinggi, manajemen mempunyai potensi yang lebih tinggi dalam melakukan kecurangan laporan keuangan. 2)Variabel effective monitoring (IND) berpengaruh negatif signifikan terhadap financial statement fraud. Hasil ini mengindikasikan bahwa semakin besar proporsi komite audit independen, maka proses monitoring terhadap peusahaan semakin efektif sehingga akan menurunkan potensi manajemen untuk melakukan kecurangan laporan keuangan. 3) Variabel personal financial need (OSHIP), financial target (ROA), nature of industry (RECEIVABLE) dan rationalization (AUDCHANGE) tidak berpengaruh signifikan terhadap kecurangan laporan keuangan. Artinya keempat variabel tersebut tidak mampu mendeteksi potensi kecurangan yang terjadi dalam perusahaan manufaktur.

Tabel 7: Hasil Uji Independent Sample T-Test

\begin{tabular}{|c|c|c|c|c|c|c|}
\hline & Kelompok & $\mathbf{n}$ & Mean & Mean Difference & T statistic & Sig- (2-tailed) \\
\hline \multirow{2}{*}{ ACHANGE } & Non Fraud & 54 &, 170633 & \multirow{2}{*}{,- 0537155} & \multirow{2}{*}{$-1,304$} & \multirow{2}{*}{, 196 } \\
\hline & Fraud & 36 &, 224348 & & & \\
\hline \multirow{2}{*}{ OSHIP } & Non Fraud & 54 & ,06840796 & \multirow{2}{*}{ 014591574 } & \multirow{2}{*}{,770 } & \multirow{2}{*}{,443 } \\
\hline & Fraud & 36 &, 05381639 & & & \\
\hline \multirow{2}{*}{ LEV } & Non Fraud & 54 &, 409217 & \multirow{2}{*}{,- 1124962} & \multirow{2}{*}{$-2,647$} & \multirow{2}{*}{,010 } \\
\hline & Fraud & 36 & ,521713 & & & \\
\hline \multirow{2}{*}{ ROA } & Non Fraud & 54 & ,081706 & \multirow{2}{*}{,- 0029502} & \multirow{2}{*}{,- 214} & \multirow{2}{*}{,831 } \\
\hline & Fraud & 36 & 084656 & & & \\
\hline \multirow{2}{*}{ RECEIVABLE } & Non Fraud & 54 &, 007122 & \multirow{2}{*}{,- 0057884} & \multirow{2}{*}{,- 830} & \multirow{2}{*}{,409 } \\
\hline & Fraud & 36 & ,012911 & & & \\
\hline \multirow{2}{*}{ IND } & Non Fraud & 54 & ,391975 & \multirow{2}{*}{ 0679012 } & \multirow{2}{*}{3,747} & \multirow{2}{*}{, 000} \\
\hline & Fraud & 36 &, 324074 & & & \\
\hline UDCHANGE & $\begin{array}{l}\text { Non Fraud } \\
\text { Fraud }\end{array}$ & $\begin{array}{l}54 \\
36\end{array}$ & $\begin{array}{r}06 \\
17\end{array}$ &,- 111 & $-1,578$ & ,121 \\
\hline
\end{tabular}

Sumber: Hasil Olah Data, 2015 


\section{Implikasi}

Penelitian ini memberi kontribusi bagi pihakpihak yang berkepentingan terhadap deteksi financial statement fraud, seperti auditor dan pemerintah dalam menilai potensi terjadinya fraud dalam perusahaan. Semakin tinggi perubahan total aset dan LEVERAGE serta semakin rendah proporsi komite audit independen dalam perusahaan, maka potensi terjadinya kecurangan laporan keuangan perusahaan tersebut semakin besar.

\section{Keterbatasan dan Saran}

Dalam penelitian ini terdapat beberapa keterbatasan yang kemungkinan dapat mempengaruhi hasil penelitian, antara lain: 1) Variabel yang digunakan untuk mendeteksi financial statement fraud pada penelitian ini hanya sebatas variabel yang dikembangkan dari Fraud Triangel Theory, yaitu tekanan, kesempatan dan rasionalisasi. Disarankan untuk menambahkan variabel independen yang dapat digunakan untuk mendeteksi terjadinya financial statement fraud, misalnya manajemen laba, perataan laba dan unexpected audit fee seperti digunakan dalam penelitian Hribar, Kravet, dan Wilson (2014). 2) Pengukuran variabel rasionalisasi dengan menggunakan proksi pergantian auditor (AUDITCHANGE), sebaiknya dikaji secara lebih baik untuk memastikan bahwa pergantian auditor tersebut bukan disebabkan karena perusahaan melaksanakan Peraturan Menteri Keuangan Republik Indonesia Nomor 17/PMK.01/2008 pasal 3 ayat 1 . Caranya adalah hanya mengelompokkan sebagai sampel perusahaan yang melakukan pergantian auditor (AUDITCHANGE) untuk perusahaan yang melakukan pergantian auditor dan laporan keuangan tahun sebelumnya mendapatkan opini selain wajar tanpa pengecualian (unqualified opinion).

\section{DAFTAR REFERENSI}

AICPA. 2002. Consideration of fraud in a financial statement audit. Statement on Auditing Standard No. 99. AICPA. New York.
Association of Certified Fraud Examinations (ACFE). 2014. Reports to the nations: On occupational fraud and abuse. Global Fraud Study.

BAPEPAM. 2002. Pedoman penyajian dan pengungkapan laporan keuangan emiten atau perusahaan-perusahaan publik. Jakarta: BAPEPAM.

Beasley, M. S., 1996. An empirical analysis of the relation betwen the board of director compositon and financial statement fraud. The Acounting Review 71 (4): 43-65.

Beasly, M., J. V. Dana, dan L. Terry. 2010. Fraudulant financial reporting. http://www.coso.org/documents/COSO FRAUDSTUDY2010 001.pdf (diakses: 13 Mei 2015).

Beneish, M. 1997. Detecting GAAP violation: Implications for assessing earnings management among firms with extreme financial performance. Journal of Accounting and Public Policy 16 (3): 271-309.

Brennan, N., dan Mc. Grath. 2007. Financial statement fraud some lesson from US and Europe: An Case studies. Journal Australia Accounting Review 17 (42): 49-61.

Committee of Sponsoring Organizations of Treadway Commission (COSO). 1999. Fraudulent Financial Reporting: 1987-1997 - Analysis of US. New York: Public Companies.

Cressey, D. 1953. Other people's money: A Study in the social psychology of embezzlement. Glencoe, IL: Free Press.

Dechow, P., R. Sloan, and A. Sweeney. 1996. Causes and consequences of earnings manipulation: An analysis of firms subject to enforcement actions by the SEC. Contemporary Accounting Research 13 (1): 1-36. 
Dunn, P. 2004. The impact of insider power on fraudulent financial reporting. Jurnal of Management 30 (3): $397-$ 412.

Ernst \& Young. 2009. Detecting financial statement fraud: What every manager needs to know.

Hribar, P., T. Kravet, dan R. Wilson. 2014. A New measure of accounting quality. Review Accounting Studies Journal 19 (1): 506-538.

Loebbecke, J., M. Eining. Dan J. Willingham. 1989. Auditor's experience with material irregularities: frequency, nature, and detestability. Auditing: A Journal of Practice and Theory 9 (1).

Lou, Y.I., dan M. L. Wang. 2009. Fraud risk factor of the fraud triangle assesing the likelihood of fraudulent financial reporting. Journal of Business and Economic Research 7 (2): 62-66.

Person, O. 1999. Using financial information to differentiate failed vs surviving finance companies in Thailand: An Implication for emerging economies. Multinational Finance Journal 3 (2): 127-145.
Skousen, C. J., K. R. Smith, dan J. C. Wright. 2009. Detecting and predicting financial statement fraud: The Effectiveness of the fraud triangle and SAS No. 99. Corporate and Firm Performance Advances in Financial Economics 13: 53-81.

Soselisa, R., dan Mukhlasin. 2008. Pengaruh faktor kultur organisasi, manajemen, strategik keuangan, dan auditor terhadap kecenderungan kecurangan akuntansi pada perusahaan publik di Indonesia. Tesis, Unika Atma Jaya Jakarta.

Spathis, C. T. 2002. Detecting false financial statements using published data: Some evidence from Greece. Managerial Auditing Journal 17 (4): 179-191.

Sukirman., dan P. S. Maylia. 2013. Model deteksi kecurangan berbasis fraud triangle (Studi kasus pada perusahaan publik di Indonesia). Jurnal Akuntansi dan Auditing 9 (2): 199-225.

Summers, S., dan J. Sweeney. 1998. Fraudulently misstated financial statements and insider trading: An Empirical analysis. The Accounting Review 73 (1): 131-146. 